Environment Conservation Journal 15(1 \&2) 223-224, 2014

ISSN 0972-3099 (Print) 2278-5124 (Online)

Abstracted and Indexed

\title{
Efficacy of NPV (Nucleopolyhedrosis virus) against C.partellus in Maize crop
}

\author{
Mrityunjay Kumar Sinha ${ }^{1} \bowtie$ and M. Mohan ${ }^{2}$
}

Received:12.10.2013

Revised: 15.02.2014

Accepted: 21.04.2014

\begin{abstract}
Indiscriminate use of pesticides for the past 40 years has almost eliminated natural enemies from many crop ecosystems. An experiment has been carried out in the laboratory to determine the efficacy of NPV (Nucleopolyhedrosis virus) against C.partellus in the stalk borer, Chilo partellus (Swinhoe) pest management during 2004-2006. The C. partellus larvae were found maximum infection at $400-500 \mathrm{ppm}$ concentration and the mortality were observed 80 to $90 \%$.
\end{abstract}

Keywords: Bio-control, maize crop

\section{Introduction}

In recent years the problem of resistance to chemical has worsened, resulting in 20-30\% crop loss due to pests in India (Bhargava et al., 2008) and causing widespread hardship especially amongst poor farmers.

Thus, considerable emphasis is being laid on the use of nuclear polyhedrosis virus (NPV) as a microbial pesticide which is species specific and ecologically safe and under certain situations they cause epizootics in the field which provide added control of pests in nature (Caballero et al., 1992; Cory et al., 1997). Use of several biopesticides increases the agricultural production but extensive and discriminate use of synthetic pesticides is likely to affect non target animals' i.e. beneficial entomofauna.Nucleopolyhedrosis virus is the most commonly used for insect pest control. When viral biocide is sprayed in the field, the viral particles get attached to the foliage and the insect larvae feed and in turn ingest the polyhedral inclusion bodies (PIB). The pib in turn multiply inside the midgut and bring about larval mortality. These protein crystals are insoluble in water and are produced in geometrical proportions and after killing the insect, get released into the surrounding atmosphere. The crystals can reinfect live insects and retain their infectivity even after long storage outside the living tissue.

\footnotetext{
Author's Address

${ }^{1}$ Deptt. of Zoology, Govt. P. G. College, Lansdowne, Pauri

2. Department of Zoology, Patna University, Patna

E-mail: mrityunjaysinha0917@gmail.com
}

\section{Material and Methods}

NPV Viruses invade an insect's body via the gut. They replicate in many tissues and can disrupt components of an insect's physiology, interfering with feeding, egg laying, and movement.. NPV infected larvae may initially turn white and granular or very dark. Some may climb to the top of the crop canopy, stop feeding, become limp, and hang from the upper leaves or stems, hence the common name "caterpillar wilt" or "tree top" disease. Victims of a granulosis virus may turn milky white and stop feeding. In both cases, the body contents of the dead larvae are liquefied and the cuticle ruptures easily to release infectious viral particles. Death from a virus infection usually occurs within three to eight days.Different dosages of NPV (in ppm) i.e. $50,100, .200,400,500 \& 1000 \mathrm{ppm}$ has been investigated against $C$. partellus mortality in the laboratory.

\section{Results and Discussion}

Table-1, showed the effect of viral (NPV) rate on mortality of C.partellus. The high mortality was observed at $500 \mathrm{ppm}$ and the least at $50 \mathrm{ppm}$.Table1 , showed the efficacy of NPV (pathogens) at different dilutions and found high mortality rate at $500 \mathrm{ppm}$ and the least at $50 \mathrm{ppm}$. Lewis and Adams (1979) also working with the black cutworm observed the highest mortality rate at $500 \mathrm{ppm}$ of NPV. Vast areas of our country are underdeveloped and general economy of farmers is at a 
very low level. Even though chemical control methods are of proven economic value, they are not extensively used carefully due to lack of expertise and cost involved, which expose the limitations in their use and efficacy. In this situation biocontrol may have considerable and long lasting value in giving a fair degree of control.

Table-1, Efficacy of NPV (Nucleo polyhedrosis virus against C.partellus

\begin{tabular}{|c|c|c|c|}
\hline $\begin{array}{c}\text { NPV dosages } \\
\text { (in ppm) }\end{array}$ & $\begin{array}{c}\text { Total No. of } \\
\text { C.partellus larvae }\end{array}$ & $\begin{array}{c}\text { NPV infected larvae of } \\
\text { C.partellus }\end{array}$ & $\begin{array}{c}\text { \% Mortality of } \\
\text { C.partellus }\end{array}$ \\
\hline 50 & 50 & 10 & $20 \%$ \\
\hline 100 & 50 & 15 & $30 \%$ \\
\hline 200 & 50 & 20 & $40 \%$ \\
\hline 400 & 50 & 40 & $80 \%$ \\
\hline 500 & 50 & 45 & $90 \%$ \\
\hline 1000 & 50 & 45 & $90 \%$ \\
\hline
\end{tabular}

\section{References}

Bhargava, M. C., Choudhary, R. K. and Jain, P. C. 2008. Genetic Engineering of plants for insect resistance. In: Entomology: Novel Approaches (Jain, P.C. and Bhargava, M. C. eds.). New India ublishing, New Delhi, India. 133144 PP.

Caballero, P., Aldebis, H. K., Varga Osuna, E. and SantiagoAlvarez, C. 1992. Epizootics caused by a nuclear polyhedrosis virus in populations of Spodoptera litura in

southern Spain. Biological Science andTechnology, 2: 3538.

Cory, J. S., Hails, R. S. and Sait, S.M. 1997. Baculovirus ecology. In: The Baculoviruses (Miller L. K. ed.). Plenum Press, New York. 301-339 PP.

Lewis,L.C. and J.R.Adams.1979. Pathogenicity of a nuclear polyhedrosis virus on to Agrotis ipsilon. J. Invert. Path. 33:253-256. 